\title{
Byssus-thread formation by the mussel Mytilus edulis: effects of environmental factors
}

\author{
G. A. Young \\ Department of Marine Science, Menai Bridge, Anglesey, North Wales, LL59 5EH, United Kingdom
}

\begin{abstract}
Temperature, excision, salinity, tidal regime, and seasonality all affected byssus production in the mussel Mytilus edulis L.; however, the most influential factor studied was agitation. Mussels agitated every $4.5 \mathrm{~s}$ produce 15.8 threads ind $\mathrm{d}^{-1} \mathrm{~d}^{-1}$, a rate twice that stimulated by any of the other factors. An acclimation period of up to $2 \mathrm{wk}$ was required for byssus-thread formation to return to that of control mussels after exposure to high temperatures, low salinities and rapid agitation. Byssus-thread production during experiments was neither random nor steady, but rather in response to a number of contributing factors, the relative importance of which will ultimately depend on the environment in which the mussel is found.
\end{abstract}

\section{INTRODUCTION}

Mytilus edulis L. is a major fouling organism in the northern hemisphere on shore-based and offshore structures (Scheer 1945, Balakrishnan Nair 1970). It uses an extra-organismal byssus complex, consisting of a variable number of threads (Tamarin et al. 1976) individually attached to solid substrata. In spite of the vast cost involved in cleaning, or using divers to clear vital inspection points, little has been done to determine which factors affect the production of byssus threads or which forces are required to dislodge them.

Information to date on the environmental factors affecting byssus production in Mytilus edulis is summarized in Table 1. All these studies were brief, lasting from a number of hours to $7 \mathrm{~d}$. The validity of results over such short periods of time must be open to doubt. Widdows \& Bayne (1971) have specified that in relation to temperature changes a minimum of $2 \mathrm{wk}$ was required for full aclimation by $M$. edulis, reemphasising work by Schlieper (1955) and Bøhle (1972) in which it was shown that enzymatic acclimation and acclimation to reduced salinities takes 4 to $9 \mathrm{wk}$. The present series of experiments was initiated to study the effect of temperature, excision, salinity, tidal regimes, seasonality and agitation over more prolonged periods.

\section{MATERIALS AND METHODS}

The following series of experiments was carried out between October 1982 and October 1983 on mussels Mytilus edulis L. attached to slate surfaces. Mussels were collected from low-tide level of a sheltered shore, Tal-y-Foel, on the Menai Strait in North Wales, individually labelled, and their shell length recorded. Although individual mussels were found consistently to produce a similar number of threads in a given period, there was much variation in the numbers produced by conspecifics of a similar size. Hence, standard error bars against the mean thread formation of groups is not very informative as individual consistency is masked by conspecific variation

Salinity, tidal regime and agitation experiments were all conducted at $15^{\circ} \mathrm{C} \pm 1 \mathrm{C}^{\circ}$. In all experiments other than seasonality, byssus threads were cut and counted each Monday, Wednesday and Friday morning. This reduced the number of loose threads which could not be related to individual mussels and also limited the extent to which mussels became entangled, thereby reducing the risk of inaccurate counting. After each thread count, the slate substratum was cleared of threads and attachment plaques before the mussels were replaced.

In all experiments except seasonality, mussels were 
Table 1. Summary of work conducted to date on the effect of a number of environmental factors on byssus-thread production

\begin{tabular}{|c|c|c|}
\hline Factor & Effect & Author \\
\hline \multirow[t]{3}{*}{ Temperature } & Increase in byssus production with increase in temperature from 18 to $28^{\circ} \mathrm{C}$ & Glaus (1968) \\
\hline & $\begin{array}{l}\text { Oxygen consumption, filtration rate and assimilation efficiency acclimated to } \\
\text { high or low temperatures in } 2 \mathrm{wk}\end{array}$ & Widdows \& Bayne (1971) \\
\hline & Increased byssus production from 3 to $18.5^{\circ} \mathrm{C}$ & Allen et al. (1976) \\
\hline \multirow[t]{3}{*}{ Salinity } & More byssus threads made at $31.3 \%$ than at 15.9 or $46.3 \%$ & Glaus (1968) \\
\hline & Byssus production decreased with declining salinity & Van Winkle (1970) \\
\hline & Reduction in salinity caused decreased numbers of byssus threads & Allen et al. (1976) \\
\hline \multirow{3}{*}{$\begin{array}{l}\text { Tidal fluctuation } \\
\text { submergence }\end{array}$} & No effect on byssus production & Martella (1974) \\
\hline & No difference in thread numbers between high and low shore populations & Price (1980) \\
\hline & No difference in byssus production with submergence & Young (1983) \\
\hline Agitation & On vigorous shaking, $33 \%$ less byssus made compared with still & Van Winkle (1970) \\
\hline \multirow[t]{3}{*}{ Water velocity } & $50 \%$ less threads in still compared with running water & Maheo $(1970)$ \\
\hline & $43 \%$ less threads in still compared with running water & Van Winkle (1970) \\
\hline & Number of threads and attachment strength increased with increasing speed & Price $(1980)$ \\
\hline Seasonality & Cycle of byssus production with maximum in Sep and minimum in May & Price (1982) \\
\hline
\end{tabular}

fed concentrated laboratory-cultured mixed microalgae 3 times a week in order to supplement the limited food available in the laboratory seawater supply.

Temperature. Fifty mussels were collected from the shore, $1 \mathrm{~m}$ above datum, on 16 November, 1982. Ambient seawater temperature was $12^{\circ} \mathrm{C} \pm 1 \mathrm{C}^{\circ}$. Specimens were brought into the laboratory and arranged into 10 groups, each of 5 individuals. Shell lengths ranged from 2.5 to $6.0 \mathrm{~cm}$. Two groups, on separate $15 \times 10 \mathrm{~cm}$ slates were placed in laboratory controlled-temperature tanks. Five temperatures, 5, 10, 15,20 and $25^{\circ} \mathrm{C}$ were tested.

Individual records of the mussels' byssus thread production were made. Specimens of 1 group at each temperature had their threads counted without disturbance before being replaced, whilst in the second group threads were first counted and then cut with sharp scissors, and the specimens replaced on a clean slate. This procedure was carried out each Monday, Wednesday and Friday and was continued over $35 \mathrm{~d}$.

Seasonal byssus production. At monthly intervals 5 mussels were placed on slate in a tank in the Menai Strait, and 5 in a similar tank in the laboratory. Seawater temperature of both environments was monitored at the beginning and end of each session. After $29 \mathrm{~d}$ the number of threads produced by each individual was counted.

Salinity. Mussels were used within 24 h of collection for each experiment. Five mussels were placed on a rectangular slate in each of six $1 \mathrm{l}$ capacity plastic boxes. Twenty experimental specimens were used for each salinity treatment, and 10 specimens in seawater (100\% at 32 to $33 \%$ ) acted as control.

Both seawater and freshwater were supplied from header tanks. The ratio of seawater to freshwater was controlled by an LKB 11300 Ultragrad gradient mixer. Each container, whilst being individually aerated, had a flow rate (control and experimental salinity) of 50 to $70 \mathrm{ml} \mathrm{min}^{-1}$, equal to a residence time in each container of 15 to $20 \mathrm{~min}$.

During salinity experiments an additional problem arose. It was found that the freshwater supply to the laboratory contained high levels of copper, $73 \mu \mathrm{gl}^{-1}$, from the copper piping. Copper concentrations of $30 \mu \mathrm{g} \mathrm{l}^{-1}$ were shown by Manley (1983) to cause a $50 \%$ reduction in normal filtration activity, and 10 to $20 \mu \mathrm{g} \mathrm{I}^{-1}$ were noted as causing serious impairment to growth and, ultimately, death. Manley et al. (1984), using a laser diffraction measuring technique, showed that as little as $10 \mathrm{ppb}$ had a significant inhibitory effect on shell growth. As the ratio of freshwater to seawater increased, the influence of copper concentration exceeded that of the reduced salinity on byssus production. Jackson \& Morgan (1978) showed that chelating agents such as ethylenediaminetetra acetate (EDTA) can detoxify normally deleterious total copper concentrations, and stated that at equilibrium $99.5 \%$ of the copper is bound to EDTA. They went on to show that detoxification of toxic metals via chelation showed a strong correlation between the growth rate of a number of phytoplankton, and free $\mathrm{Cu}^{2+}$ at equilibrium in solution. Whilst bearing in mind that the addi- 
tion of very high concentrations of powerful chelators, such as EDTA, may decrease both growth rate and concentration of free metal ions, EDTA was added to prevent mortality of mussels by copper poisoning. A $0.001 \mathrm{M}$ solution of EDTA in distilled water was delivered by means of a peristaltic pump, to both freshwater and seawater $20 \mathrm{l}$ capacity header tanks at a rate of $5 \mathrm{l}$ (i.e. $1.86 \mathrm{~g}$ EDTA) per tank per day. This resulted in a $0.0005 \mathrm{M}$ solution of EDTA being dispensed to each experimental tank.

Tidal submergence. Twenty mussels were collected on 14 February 1983, when the ambient sea temperature was $5^{\circ} \mathrm{C} \pm 1 \mathrm{C}^{\circ}$, and divided into 4 groups each of 5 individuals, with a shell length range of 2.3 to $5.7 \mathrm{~cm}$.

One group was placed on each of 4 levels of a specially designed, transparent perspex, tidal simulation tank, in which seawater ebbed and flooded on a $12 \mathrm{~h}$ cycle. Specimens on Level 1 (the top) were exposed for 10 out of every $12 \mathrm{~h}$, those on Level 2 for 8 out of every $12 \mathrm{~h}$, those on Level 3 for 6 out of every $12 \mathrm{~h}$, whilst those on Level 4 , the tank bottom, were continuously submerged.

In this experiment the valves were initially closed so that water flowed through an overflow pipe. After $2 \mathrm{~h}$ the top valve opened and acted as the overflow pipe, allowing mussels on the uppermost platform to be exposed. After $4 \mathrm{~h}$ the second valve opened; after $6 \mathrm{~h}$ the third valve successively exposed the mussels, simulating a gently ebbing tide. Twelve $h$ from the commencement of the cycle, all 3 valves closed and the tank refilled to the overflow level. Refill took approximately $15 \mathrm{~min}$, whilst each decrease in level subsequent to a valve opening took 3 to $5 \mathrm{~min}$.

The number of byssus threads by which each individual was attached, and the number found loose on the slate, were counted over a period of $41 \mathrm{~d}$.

Agitation. An apparatus was designed specifically to agitate the mussels. It consisted of a variable speed motor with thyristor control, driving a horizontal shaft. Along the shaft were 6 cogs, each with a coinciding, projecting, grooved knob. A beam ran behind, and parallel with, the shaft. A piece of string, tied at 1 end to the beam, ran over each cog, passed down through a guiding hole, and was firmly glued at the other end to a mussel. The 6 mussels tested at each speed were maintained on slates within a $5 \mathrm{~cm}$ deep seawater bath. During each rotation of the shaft, the knob caught the string and, passing over the asymmetric cog, the string was pulled, resulting in the mussel being raised about $1 \mathrm{~cm}$. Care was taken in ensuring that the length of string was sufficient to allow movement of the mussel without any danger of rupturing the byssal attachments.

Mussels were labelled and kept initially in still seawater for $1 \mathrm{wk}$, during which time the number of bys- sus threads produced was recorded. They were then agitated for $2 \mathrm{wk}$ at one of 3 speeds before being returned to still water. The speeds chosen were:

Slow: $27 \mathrm{~s}=$ Wave period for Criccieth, North Wales (Lewis 1981)

Medium: $9 \mathrm{~s}=$ Wave period for Cable Bay, Anglesey (Lewis 1981)

Fast: $4.5 \mathrm{~s}$.

\section{RESULTS AND DISCUSSION}

\section{Temperature, excision, seasonality}

The effect of temperature on byssus-thread number is shown in Fig. 1 and Table 2. Mussels at $25^{\circ} \mathrm{C}$ dis-

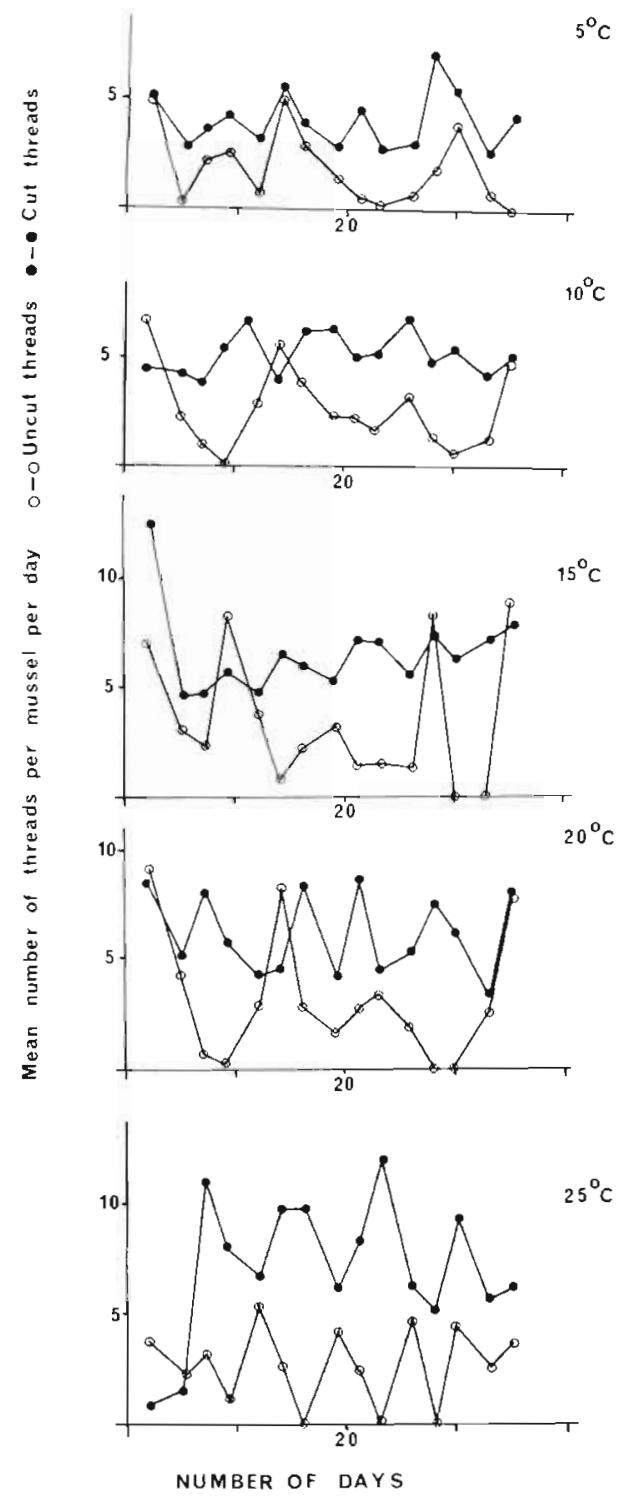

Fig. 1. Mytilus edulis. Effects of increasing temperature and excision on byssus-thread production over a period of $35 \mathrm{~d}$ 
Table 2. Mytilus edulis. Effect of temperature and excision on byssus thread production over $35 \mathrm{~d}$

\begin{tabular}{|c|c|c|c|}
\hline \multirow[t]{2}{*}{$\begin{array}{l}\text { Temperature } \\
{ }^{\circ} \mathrm{C}\end{array}$} & \multicolumn{2}{|c|}{$\begin{array}{l}\text { No. of byssus threads } \\
\text { produced ind } d^{-1} \mathrm{~d}^{-1}\end{array}$} & \multirow{2}{*}{$\begin{array}{l}\text { Mean number of } \\
\text { byssus threads by } \\
\text { which 'uncut' mus- } \\
\text { sels were attached at } \\
\text { end of experiment }\end{array}$} \\
\hline & $\begin{array}{c}\text { Cut } \\
\text { Mean } \pm \text { SE }\end{array}$ & $\begin{array}{c}\text { Uncut } \\
\text { MeantSE }\end{array}$ & \\
\hline 5 & $3.92 \pm 0.57$ & $1.62 \pm 0.74$ & 19.2 \\
\hline 10 & $5.13 \pm 0.41$ & $2.55 \pm 0.78$ & 49.2 \\
\hline 15 & $6.56 \pm 0.83$ & $3.40 \pm 1.28$ & 68.4 \\
\hline 20 & $6.09 \pm 0.83$ & $3.18 \pm 1.22$ & 55.4 \\
\hline 25 & $6.86 \pm 1.35$ & $2.81 \pm 0.76$ & 42.2 \\
\hline
\end{tabular}

played a period of acclimation lasting approximately $7 \mathrm{~d}$. Mussels whose byssus threads were cut made 2 threads $\mathrm{d}^{-1}$ during this period, whereas for the rest of the experiment they made between 6 and 12 threads $\mathrm{d}^{-1}$. Mussels at lower temperatures $\left(5\right.$ to $20^{\circ} \mathrm{C}$ ) did not display a period of acclimation.

It was immediately apparent that detaching specimens, by cutting the byssus threads, caused a substantial increase in thread production. In an earlier study lasting only $10 \mathrm{~d}$ (Young 1983a), in which the byssus threads were counted each day without cutting, it was found that each individual $(n=10)$ made approximately 8 threads during the first $24 \mathrm{~h}$, after which there was a steady increase in the overall number of attachment threads at the rate of 1 to 2 threads $d^{-1}$. This earlier experiment predicted that 8 to 11 threads would be formed (at $13^{\circ} \mathrm{C}$ ) during the initial $3 \mathrm{~d}$, giving a mean production rate of 3.5 threads $d^{-1}$. This rate corresponds well with the observed production in the present experiment at $10^{\circ} \mathrm{C}$; however thread production increases with temperature. Mussels whose byssus threads were counted but not cut, made only a few new threads $\left(<2 \mathrm{~d}^{-1}\right)$ after the initial $48 \mathrm{~h}$. These results correspond well with those of Mahéo (1970).

It is interesting to note that the mussels could continue to produce threads at a fast rate $\left(>6 \mathrm{~d}^{-1}\right)$ with no apparent reduction in vigour throughout the temperature experiment.

Byssus threads detached by the mussel itself were found most often on those slates frequented by mussels whose byssus threads were not artifically cut, and less frequently when mussels had their threads regularly

Table 3. Total number of threads found unattached on the slate surface during a $35 \mathrm{~d}$ period

\begin{tabular}{|ccc|}
\hline Temperature $\left({ }^{\circ} \mathrm{C}\right)$ & Threads cut & Threads uncut \\
\hline 5 & 78 & 178 \\
10 & 226 & 216 \\
15 & 295 & 239 \\
20 & 139 & 278 \\
25 & 68 & 281 \\
\hline
\end{tabular}

cut (Table 3). Allen et al. (1976) noted that at low temperatures most of the byssus threads remained in use, but as the temperature rose the mussels became more mobile. This conclusion is supported by the results of the present study (Table 3 ) where mussels whose byssus threads were not cut showed an increase in mobility with temperature, reflected by the number of naturally detached byssus threads found. However, when the mussels are regularly detached artificially using scissors, their main effort is then put into reattachment rather than exploration.

Mussels in the field in more exposed areas, such as on rocks on Tan-y-Foel on the Menai Strait, have more byssus threads (87 threads ind ${ }^{-1}$; sample of 50 ; $\mathrm{SE}=4.7$ ) than do the experimental mussels. This compares with field specimens from sheltered sites which have thread counts ( 48 threads ind ${ }^{-1}$ : mussel beds at Tan-y-Foel; sample of 50; $\mathrm{SE}=3.15$ ) which approximate to the number of threads made by laboratory specimens over a period of $35 \mathrm{~d}$. These numbers are very low in relation to the mussel's potential for byssus production under laboratory conditions. Mussels whose byssus threads were cut 3 times a week made from 142 threads at $5^{\circ} \mathrm{C}$, to 249 threads at $25^{\circ} \mathrm{C}$, during the $35 \mathrm{~d}$ period. The most productive individual $\left(4.72 \mathrm{~cm}\right.$ long) was kept at $25^{\circ} \mathrm{C}$ with the byssus regularly cut; it made a total of 378 threads in $35 \mathrm{~d}$, not accounting for any that it may have made and left detached on the surface.

The number of byssus threads made by the laboratory mussels varied throughout the year. The largest number of threads were made during June to August, with a maximum of 7.8 threads ind ${ }^{-1} \mathrm{~d}^{-1}$ (seawater temp. 19 to $21^{\circ} \mathrm{C}$ ) in July, whilst the lowest numbers of threads were formed during December to March with a minimum in February of 3.2 threads ind ${ }^{-1} \mathrm{~d}^{-1}$ (seawater temp. $5^{\circ} \mathrm{C}$ ).

Data in Fig. 2 show that thread formation follows seawater temperature closely. Conditions of water flow in the tank in which the mussels were kept remained identical throughout the year. Although temperature is the most obvious candidate as the factor affecting byssus production in this experiment, others must also be taken into consideration. These include varying photo periods, available food and chlorophyll a concentrations (and hence phytoplankton), which show a maximum in June, together with the metabolic phase of the mussel, it being likely that at times a high energy output is demanded, for example when the animals spawn.

Results shown in Fig 2 show that byssus-thread production by mussels in the field is double that of laboratory specimens. This is in spite of the fact that laboratory seawater temperatures are consistently higher than in the field. The over-riding factor varying 
Fig. 2. Mytilus edulis. Seasonal byssus-thread production. Comparison over $29 \mathrm{~d}$ periods, in both field and laboratory during 1983. Laboratory and field seawater temperatures are also given
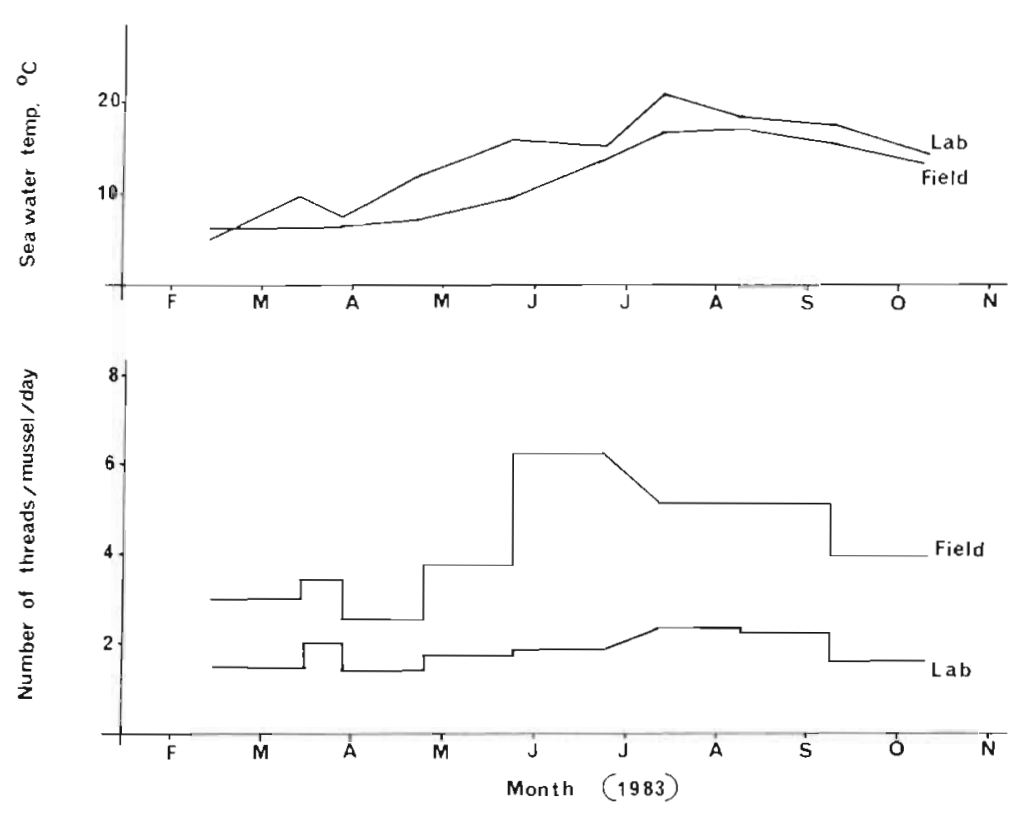

between field and laboratory is that in the field the mussels would have been constantly agitated by both waves and tides.

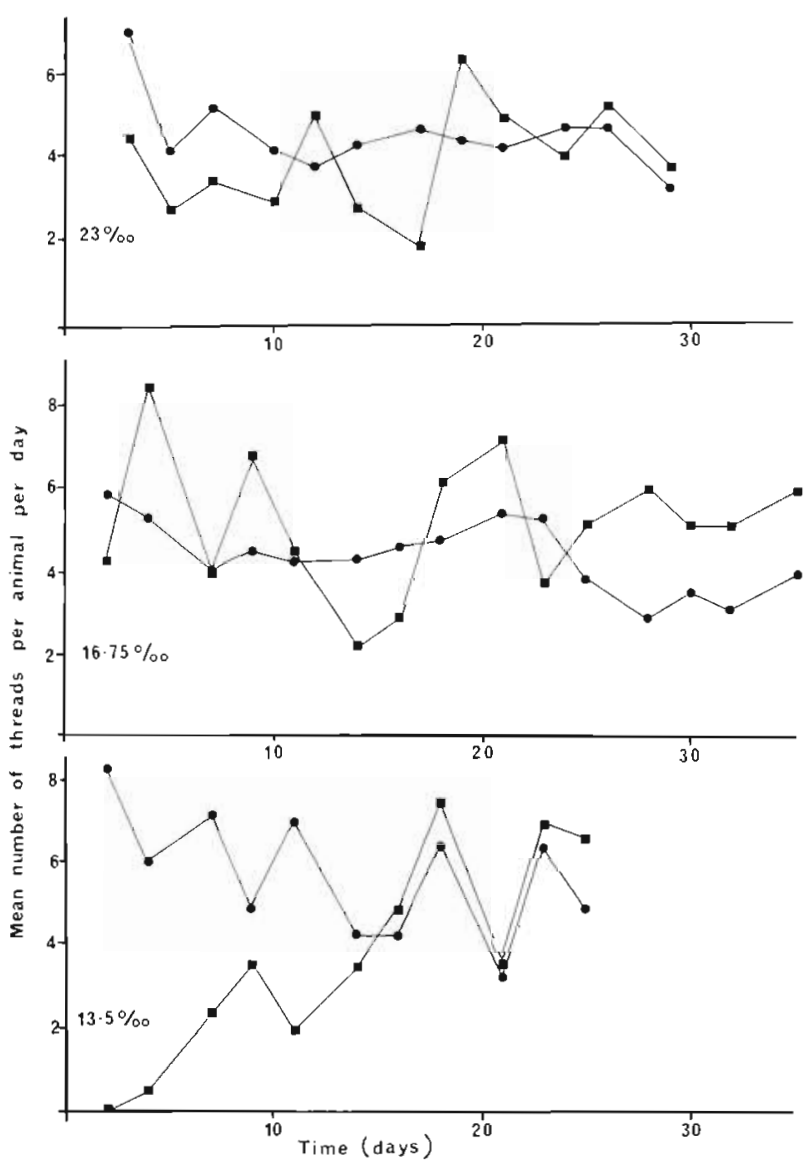

Fig. 3. Mytilus edulis. Effect on byssus-thread production when mussels are placed directly into $23,16.75$ and $13.5 \%$. Circles: $33 \%$; squares: experimental salinity

\section{Salinity}

EDTA was added to the waters in all these experiments, in order to counteract the toxic effect of copper within the freshwater supply (see 'Materials and Methods').

Specimens were taken from the field and placed directly into tanks containing 23, 16.75, 13.5 and $10.5 \%$. The effect of reduction in salinity on byssus production is shown in Fig. 3. Control specimens made approximately 4 to 6 threads ind $\mathrm{d}^{-1} \mathrm{~d}^{-1}$. Mussels in both 23 and $16.75 \%$ produced similar numbers of byssus threads to those in full salinity. However, when specimens were placed directly into $13.5 \%$, byssus thread formation was severely reduced during the first week, increased gradually over the second week, after which it again matched that of the controls. Mussels placed in $10.5 \%$ did not produce any byssus threads, and died within the first week.

It is known that Mytilus edulis does in fact survive in the Gulf of Finland in salinities of 4 to $5 \%$ (Segerstråle 1957). This fact together with the present evidence that mussels in $13.5 \%$ had eventually acclimated after $2 \mathrm{wk}$, although filtration rate and byssus production had initially been severely depressed, led to speculation as to whether coastal marine mussels would survive and make attachment threads in lower salinities, if acclimation took place progressively. Two further experiments were then performed, in which specimens were placed (a) from $33 \rightarrow 16.75 \rightarrow 13.5 \%$, and (b) from $33 \rightarrow 13.5 \rightarrow 10.5 \rightarrow 8.5 \%$, and their byssus production monitored. Results are plotted in Fig. 4 and clearly show that after a period of acclimation to $16.75 \%$, recovery time after lowering to $13.5 \%$ is only $3 \mathrm{~d}$, as compared to $14 \mathrm{~d}$ when mussels are transferred 


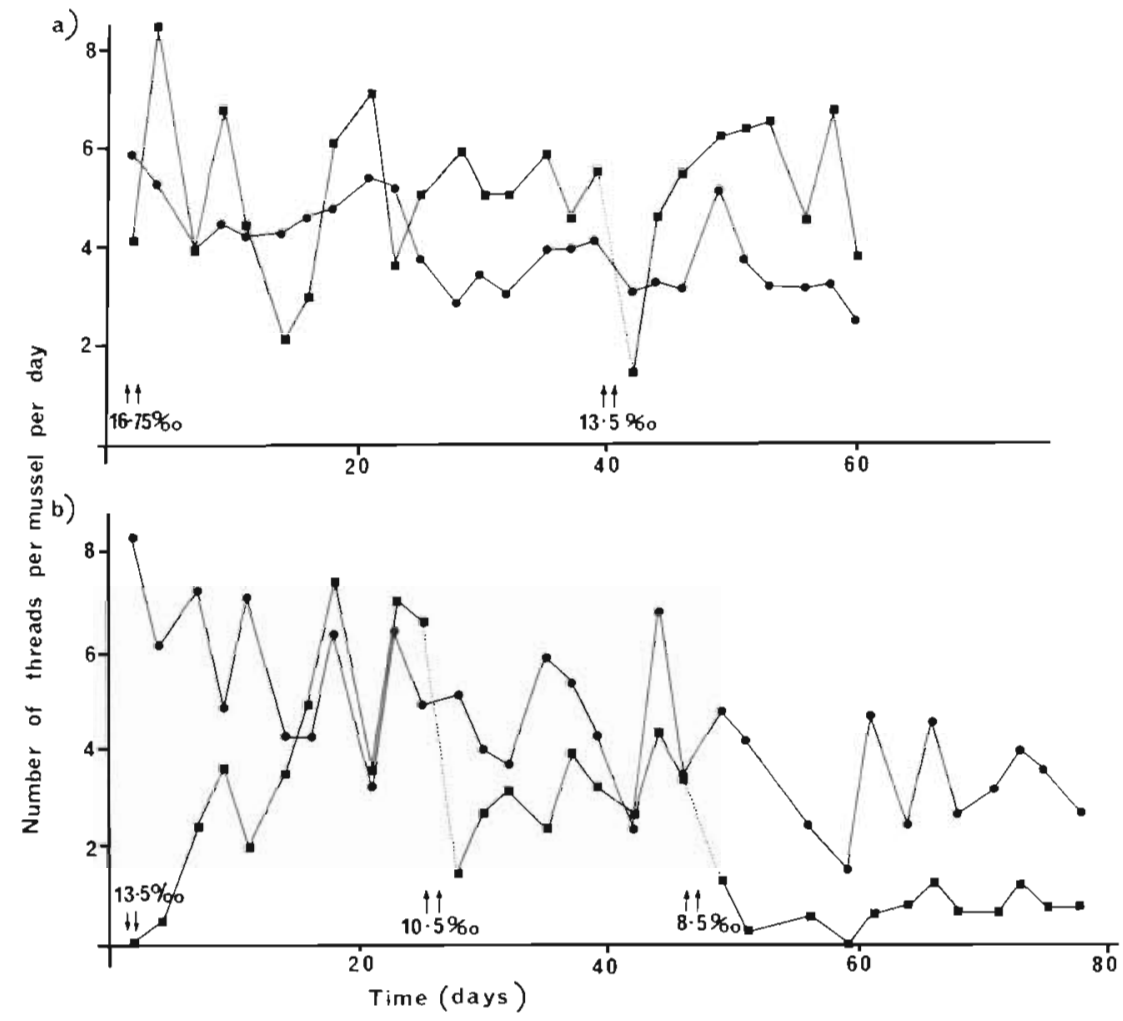

Fig. 4. Mytilus edulis. Acclimation to successively reduced salinity. (a) From $33 \rightarrow 16.75 \rightarrow 13.5 \%$; (b) from $33 \rightarrow 13.5$ $\rightarrow 10.5 \rightarrow 8.5 \%$. Circles: $33 \%$; squares: experimental salinity directly from $33 \rightarrow 13.5 \%$. Specimens acclimated to $13.5 \%$ (Fig. 4 b) can survive well when salinity is reduced to $10.5 \%$. At this new level byssus production initially falls, but within $6 \mathrm{~d}$ rises to the same level as that of the controls. It is not until the salinity is reduced further that a permanent decline in byssus production results.

Although unable to survive large changes in salinity, mussels were able to acclimate in relatively short periods to low salinities approaching those found in the more extreme natural environments (Segerstråle 1957).

This ability to acclimate to steadily reducing salinity, whilst maintaining an almost constant byssus production, follows a similar trend to that shown in relation to the heart rate and gill ciliary beat of mussels. Pilgrim (1953a) placed isolated, rhythmically-contracting preparations of cardiac muscle of Mytilus edulis directly into reduced salinities, resulting in a temporary shock-reaction followed by recovery, i.e. a reduction in amplitude or cessation of contractions followed by adaptation. He noted that such reactions could be avoided if the salinity was reduced slowly. When using isolated gill preparations, Pilgrim (1953b) noted that there was no effect to the ciliary beat when the salinity was reduced from 33 to $13.5 \%$. However, when reduced from 33 to $10.5 \%$, the beat of the frontal cilia was inhibited for 4 to $14 \mathrm{~min}$, and after direct placement into $8.5 \%$ only some of the cilia continued to beat. Salinities affecting heart rate and ciliary beat concur well with those affecting production of byssus. In $8.5 \%$ less than 1 thread ind ${ }^{-1} \mathrm{~d}^{-1}$ is made in contrast to the 3.5 threads ind ${ }^{-1} \mathrm{~d}^{-1}$ of the control sample. During the longer-term experiments, byssus production by the controls started at 4.8 threads ind ${ }^{-1} \mathrm{~d}^{-1}$ and declined slowly to 3 to 4 threads ind $d^{-1} \mathrm{~d}^{-1}$.

In relation to the formation and functioning of the byssus apparatus, mussels can fully adapt to reduced salinity as low as 9 to $10 \%$. They can then continue successfully to form byssus threads, although at a much reduced rate, at 7 to $8 \%$, a remarkable physiological capability for an animal which is iso-osmotic with its surrounding medium (Schlieper 1955).

\section{Tidal regimes}

The variation in the mean number of threads made by an individual mussel each day at different stimulated tidal levels over a period of $41 \mathrm{~d}$ is illustrated in Fig. 5. When the levels are observed separately and the 5 mussels treated individually, there is no difference in thread production between individuals on Level 1 ( $P>0.001)$, but there are differences between those on Levels 2, 3 and 4. Results of a 2-way analysis of variance are given in Table 4 ; it shows that difference in submergence level and variation with time are significant. The interaction, however, was not signifi- 

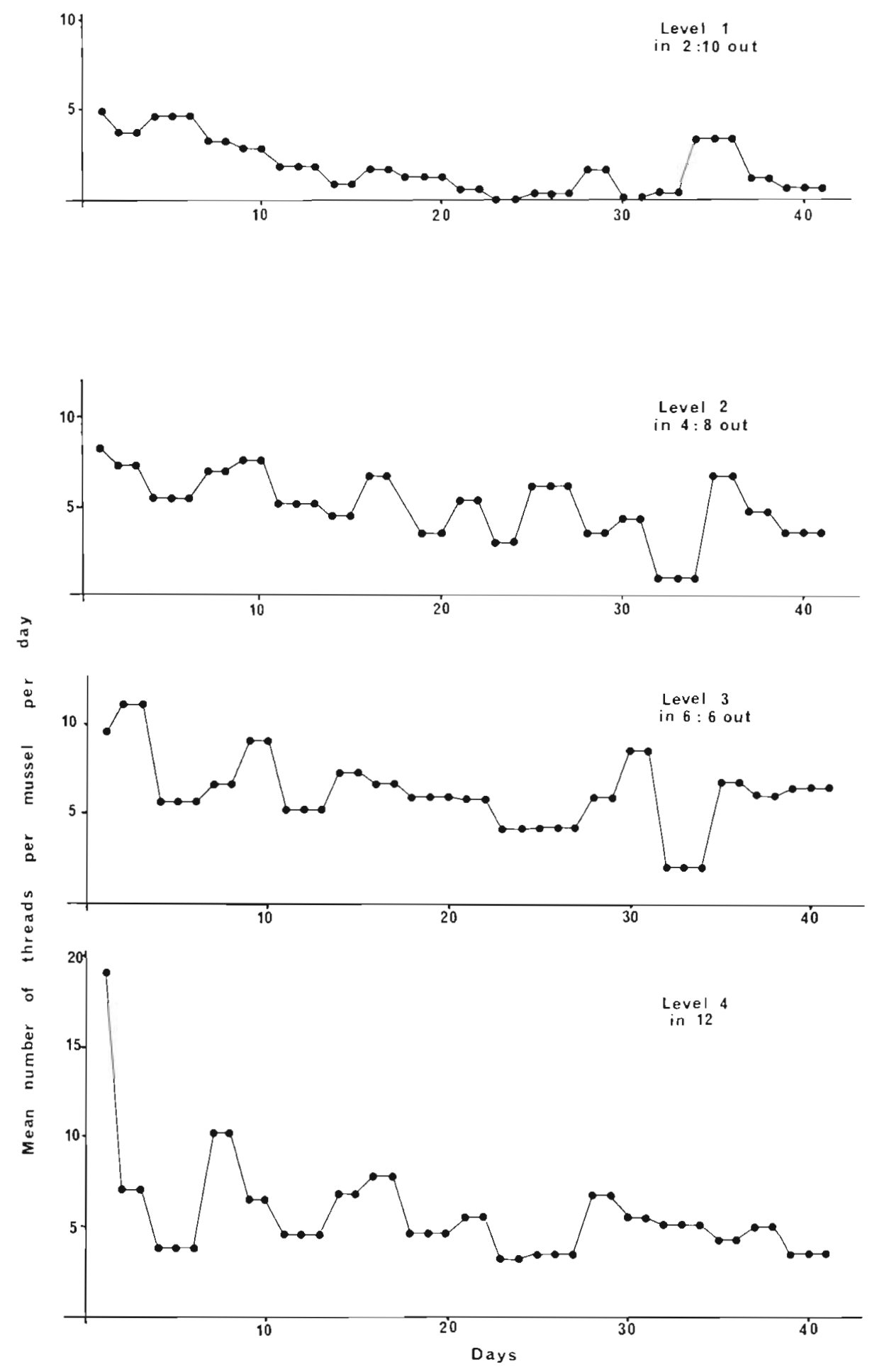

Fig. 5. Mytilus edulis. Mean number of threads ind ${ }^{-1} \mathrm{~d}^{-1}$, in 4 different tidal regimes, recorded against time over a period of $41 \mathrm{~d}$ at $15^{\circ} \mathrm{C}$

cantly different from the error variance. Table 5 shows that the variation in thread formation, indicated in Table 4 , in response to varying submergence regimes by the 4 groups of mussels can be accounted for entirely by the mussels on the uppermost platform (Level 1). The probability of finding an erroneous sig- nificant result in any of these tests is at most 0.05 (T $5 \%$ ). Production of byssus declines with time. Mussels on Level 1 showed an apparent loss of vigour and during the experiment 2 individuals died. The first death was on Day 26 and the second on Day 33. On the other levels, however, reduction in thread formation 
Table 4. Two-way analysis of variance: submergence level $x$ duration (d)

\begin{tabular}{|lcccc|}
\hline $\begin{array}{c}\text { Source of } \\
\text { variation }\end{array}$ & $\begin{array}{c}\text { Sum of } \\
\text { squares }\end{array}$ & $\begin{array}{c}\text { Degrees of } \\
\text { freedom }\end{array}$ & $\begin{array}{c}\text { Mean } \\
\text { squares }\end{array}$ & $F$ \\
\hline $\begin{array}{l}\text { Submergence } \\
\text { level }\end{array}$ & 770.71 & 3 & 256.90 & $19.81 \cdots$ \\
$\begin{array}{l}\text { Days } \\
\text { Submergence } \\
\text { level } \times \text { days }\end{array}$ & 522.90 & 51 & 10.25 & 0.79 \\
$\begin{array}{l}\text { Replicates } \\
\text { Total }\end{array}$ & 3735.88 & 288 & 12.97 & \\
... Significant at $P=<0.01$ & 17 & 57.77 & $4.45 \cdots$ \\
& 6011.56 & 359 & & \\
\end{tabular}

was not readily apparent, individual mussels showing bursts of byssus thread production interspersed with quiescent periods.

The effect of aerial exposure on mussels has been studied by an number of workers. Van Winkle (1970) subjected groups of 16 Modiolus demissus to $0 \mathrm{~h}, 25 \mathrm{~h}$ and $48 \mathrm{~h}$ exposure $\left(22\right.$ to $28^{\circ} \mathrm{C}$ ) and found that on resubmergence their resultant byssus thread production was approximately $1.3,2.1$ and 3.0 threads ind $^{-1} \mathrm{~h}^{-1}$ respectively. Several other examples can be cited indicating that the activity of an intertidal organism is often increased following exposure to air. Helm \& Trueman (1967) found that the heart rate of Mytilus edulis accelerated rapidly on immersion after $3 \mathrm{~h}$ exposure to air and often exceeded the rate recorded during normal siphoning activity. They also observed similar results in the field during the natural tidal cycle. Moon \& Pritchard (1970) determined that when Mytilus californianus from high and low shore populations were exposed to air for periods of 6 to $12 \mathrm{~h}$, there was a marked rise in oxygen consumption and accumulated lactate in the high-level mnussels. They concluded that a consequence of a high shore existence is the capacity for anaerobiosis during exposure with a corresponding increase in metabolic rate during immersion.

In the present study it would seem likely that the decline of byssus production on Level 1 is a direct

Table 5. Mytilus edulis. Mean byssus thread formation on Levels 1 to 4 , and least significant difference (T $5 \%$ )

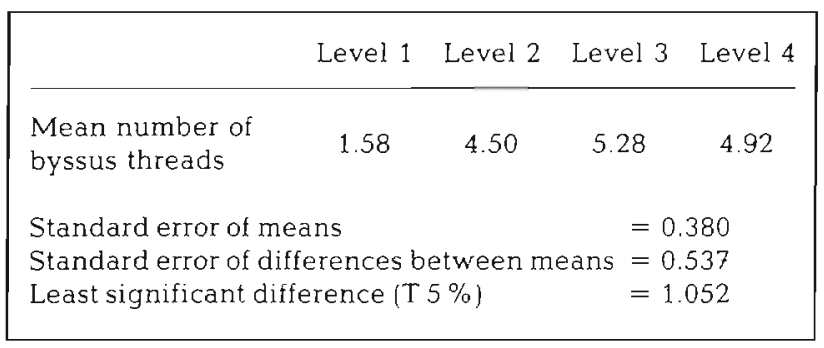

result of the limited immersion time. Such a decline contrasted markedly with the results from Level 2 , where the mussels were immersed for $4 \mathrm{~h}$ out of $12 \mathrm{~h}$, and produced almost as many byssus threads as the continually submerged animals.

Although not statistically different from Levels 2 or 4 , mussels on Level 3 produced the most byssus threads. Such production may be due to a number of factors. An increase in heart beat or in metabolic rate could be such as to outweigh the disadvantage of the $6 \mathrm{~h}$ period of exposure. Or, it may be that the ebb and flow of the water in the tank agitates these animals most, and promotes increased byssus production. Both Glaus (1968) and Price (1980) observed the effect of changes in current velocity, and both found that an increase in current velocity was followed by an increase in byssus thread production.

\section{Agitation}

Results from the agitation experiment are given in Fig. 6 and show clearly that with increasing frequency of agitation there is a marked increase in byssus production. Mussels agitated every $4.5 \mathrm{~s}$ made more than twice as many threads as those pulled only every $27 \mathrm{~s}$. Another interesting feature shown by this experiment was the extent to which the animals were able to acclimate. Initial byssus production was high, both when the animals were first placed in still water and when agitation commenced. After each of these events daily thread production fell to approximately half the initial level.

Response to agitation was immediate, mussels producing 20 to 25 threads ind $\mathrm{d}^{-1} \mathrm{~d}^{-1}$ for a number of days after the disturbance began, but dropping rapidly within $24 \mathrm{~h}$ of its ceasing. The response to disturbance found here concurs with field work by Price (1982) in which she found an increase in mussel attachment strength occurred, with little or no lag, after strong westerly Atlantic winds and the resultant wave action. She did, however, find that once stimulated, the attachment strength of the mussels remained at an inflated level for $29 \mathrm{~d}$ after the storm. I would suggest that this is the result of extra byssus threads being formed during the rough weather, resulting in a stronger byssus complex, rather than a continued increase in byssus thread number over a protracted period. The ability to acclimate is of considerable ecological importance, because the more rapidly the animals are able to respond to changes in wave frequency and storm surge by increasing byssal attachment strength, the lower will be the mortality.

Mussels attach to high energy surfaces, e.g. slate, after minimal exploration of the surface. However, on 


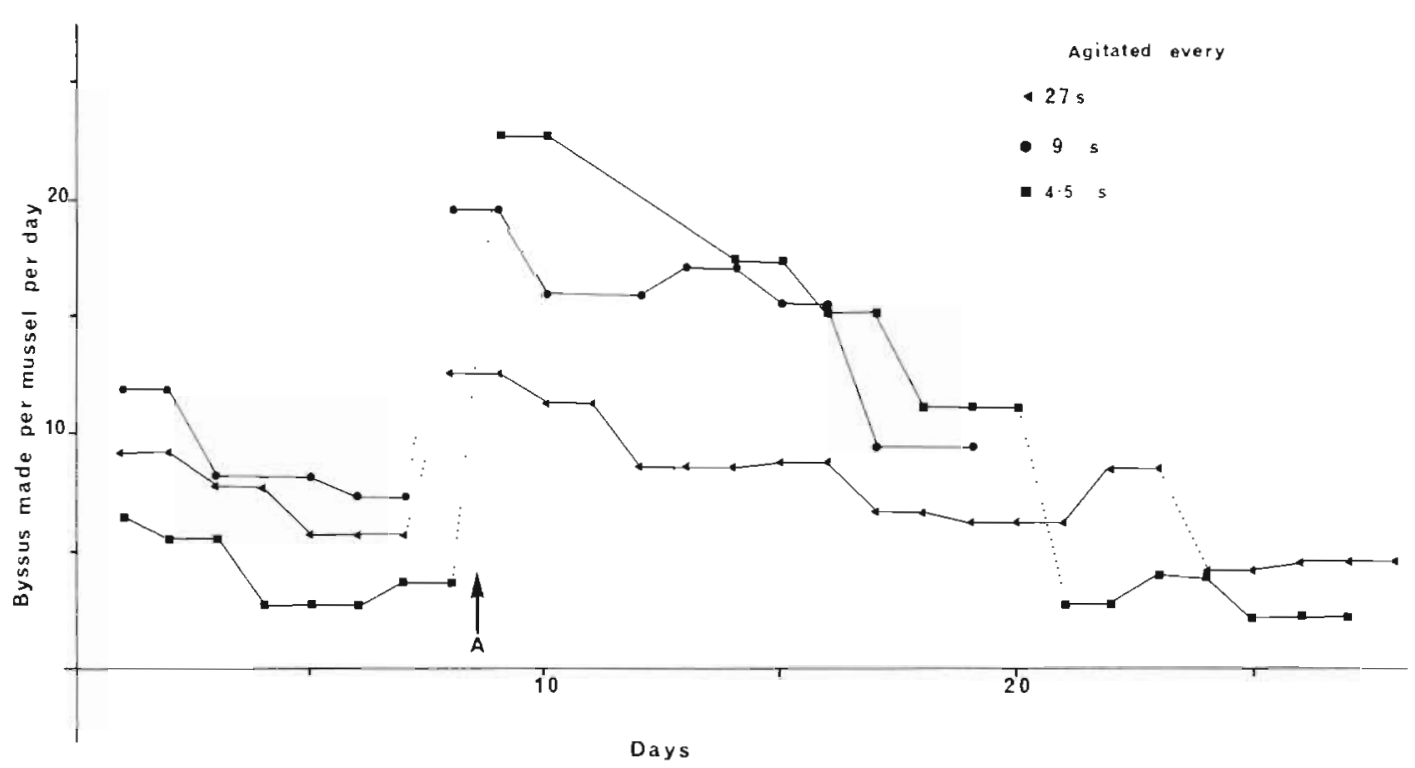

Fig. 6. Mytilus edulis. Effect of agitation on byssus-thread production. A: commencement of agitation

less attractive surfaces they will move some considerable distance and on contact with other mussels will attach byssus threads to each others' periostracum in preference to the solid surface substratum (Young 1983b); as a result clumps develop, characteristic of mussel beds. Individuals in the centre of a clump are at an advantage in that the physical forces of moving water exerted upon them are less than those upon individuals at the periphery. Martella (1974) stated that individuals involved in clumping activity actually formed more byssus threads than did isolated individuals. Witman \& Suchanek (1984), however, found that less force was required to dislodge Mytilus californianus from the centre of the mussel bed than from the edge, lending weight to the quoted observation by J. H. Connell (Harger \& Landenberger 1971) that mortality in beds of $M$. edulis on the coast of Scotland was highest in dense beds where many mussels were attached to other mussels rather than to solid substrata. Paine \& Levin (1981), whilst observing patches within the $M$. californianus beds on Tatoosh Island, Washington, USA, noted that heavy losses within a bed in $1 \mathrm{yr}$ resulted in relative immunity to destruction during the next 2 to 4 yr and not until after this time did damage occur. These cycles of destruction can be explained by cyclical mortality/attachment of small mussels directly on to the substratum. Paine \& Levin (1981) proposed that continued wave jostling might increase the number of threads by which each mussel was attached and hence reduce loss.

From the present agitation experiments it is apparent that mussels have a capability to respond to changes in wave force; they are able to increase the number of attachment threads by $25 \%$ within $8 \mathrm{~h}$ of a storm commencing. However, they will still be vulnerable to the effect of a sudden squall, during which they may be swept off rocks, or from the mussel bed, resulting in high mortalities (Harger \& Landenberger 1971 , Dare 1975).

\section{CONCLUSIONS}

Mussels, because of their littoral habitat, are subject to considerable buffeting by both tide and waves. Their survival is largely the result of their ability to form a strong attachment in order to withstand the large forces imparted by both shock and surge (up to $16 \mathrm{~m} \mathrm{~s}^{-1}$; re-interpreted from Jones \& Demetropoulos 1968, in Vogel 1981).

All the environmental factors investigated in this study were found to have some effect on byssus formation in Mytilus edulis either directly or as a result of a change in the mussels metabolic rate. The most powerful effect was that of agitation which was observed both directly and during tidal regime and seasonality experiments. Direct agitation was shown to stimulate a maximum of 25 threads ind $d^{-1} \mathrm{~d}^{-1}$ (Fig. 6) with a mean of 15.81 threads ind $\mathrm{d}^{-1} \mathrm{~d}^{-1}$ (Table 6$)$, whilst in all other experiments less than 8 threads ind ${ }^{-1} \mathrm{~d}^{-1}$ were made (Table 6). The effect of agitation in the field was shown also in the seasonality experiment. Mussels produced twice as many threads, in both summer and winter, in the field than they did in the laboratory (Table 6).

On the basis of the experimental results reported here it can be concluded that byssus threads are produced neither randomly nor steadily. Rather they are made in response to a number of contributing factors, 
Table 6. Mytilus edulis. Comparison of effects of 5 environmental factors on byssus production. In all the experiments except seasonality, threads were cut each Mon., Wed. and Fri. In the seasonality experiment, threads were counted at the end of a $29 \mathrm{~d}$ period

\begin{tabular}{|c|c|c|c|c|}
\hline $\begin{array}{c}\text { Environmental } \\
\text { factor }\end{array}$ & No. of days & No. of specimens & $\begin{array}{c}\text { Mean no. of threads } \\
\text { ind } d^{-1} \mathrm{~d}^{-1}\end{array}$ & $\pm \mathrm{SE}$ \\
\hline \multicolumn{5}{|l|}{ Temperature $\left({ }^{\circ} \mathrm{C}\right)$} \\
\hline 5 & 35 & 5 & 4.06 & 0.59 \\
\hline 10 & 35 & 5 & 5.13 & 0.39 \\
\hline 15 & 35 & 5 & 6.72 & 0.86 \\
\hline 20 & 35 & 5 & 6.17 & 0.81 \\
\hline 25 & 35 & 5 & 7.13 & 1.38 \\
\hline \multicolumn{5}{|l|}{ Salinity $(\%)$} \\
\hline 23 & 29 & 20 & 3.79 & 0.27 \\
\hline 16.75 & 39 & 20 & 5.09 & 0.35 \\
\hline 13.5 & 25 & 20 & 3.65 & 0.50 \\
\hline 10.5 & 21 & 20 & 2.83 & 0.18 \\
\hline 8.5 & 31 & 20 & 0.70 & 0.09 \\
\hline \multicolumn{5}{|l|}{ Agitation } \\
\hline still & 7 & & 7.30 & 0.42 \\
\hline every $27 \mathrm{~s}$ & 16 & 6 & 8.93 & 1.69 \\
\hline still & 7 & 6 & 8.93 & 1.83 \\
\hline every $8 \mathrm{~s}$ & 13 & 0 & 14.70 & 4.48 \\
\hline still & 9 & & 4.43 & 0.92 \\
\hline every $4.5 \mathrm{~s}$ & 9 & 6 & 15.80 & 1.84 \\
\hline \multirow{2}{*}{\multicolumn{5}{|c|}{$\begin{array}{l}\text { Tidal regime } \\
\text { In : Out }(\mathrm{h})\end{array}$}} \\
\hline & & & & \\
\hline $2: 10$ & 41 & 5 & 1.70 & 0.66 \\
\hline $4: 8$ & 41 & 5 & 4.91 & 0.81 \\
\hline $6: 6$ & 41 & 5 & 6.19 & 0.91 \\
\hline $12: 0$ & 41 & 5 & 5.71 & 1.21 \\
\hline \multicolumn{5}{|l|}{ Seasonality } \\
\hline Field; Feb & 29 & 5 & 3.01 & 11.46 \\
\hline Lab; Feb & 29 & 5 & 1.57 & 7.18 \\
\hline Field; Jul & 29 & 5 & 5.12 & 24.51 \\
\hline Lab; Jul & 29 & 5 & 2.36 & 9.05 \\
\hline
\end{tabular}

and the relative importance of these factors will vary depending on the changing conditions of the continuously dynamic environment in which the mussel is found.

Acknowledgements. I thank the staff of the N.E.R.C. Unit for help in maintenance of equipment and provision of microalgae, and also Dr. G. Walker, Dr. J. Davenport and Professor D. J. Crisp for useful discussions. This work was undertaken with S.E.R.C. Grant No. 9R/B/8874.7 (NW/B/8.18).

\section{LITERATURE CITED}

Allen, J. A., Cook, M., Jackson, D. J., Preston, S., Worth, E. N. (1976). Observations on the rate of production and mechanical properties of the byssus threads of Mytilus edulis L. J. Mollusc. Stud. 42: 279-289

Balakrishnan Nair, N. (1970). The role of molluscs in marine fouling. Proc. Sym. Moll. Part III. J. mar. biol. Ass. India 1970: $712-717$
Bøhle, B. (1972). Effects of adaptation to reduced salinity on filtration activity and growth of mussels (Mytilus edulis L.). J. exp. mar. Biol. Ecol. 10: 41-47

Dare, P. J. (1975). Settlement, growth and production of the mussel Mytilus edulis L. in Morecombe Bay. Fish. Inv. M.A.F.F. Lond. Ser. II. 28: 25

Glaus, K. J. (1968). Factors influencing the production of byssus threads in Mytilus edulis. Biol. Bull. mar. biol. Lab., Woods Hole 135: 420

Harger, J. R. E., Landenberger, D. E. (1971). The effect of storms as a density dependent mortality factor on populations of sea mussels. Veliger 14: 195-201

Helm, M. M., Trueman, E. R. (1967). The effect of exposure on the heart rate of the mussel, Mytilus edulis L. Comp. Biochem. Physiol 21: 171-177

Jackson, G. A., Morgan, J. J. (1978). Trace metal-chelator interactions and phytoplankton growth in sea water media: Theoretical analysis and comparison with reported observations. Limnol. Oceanogr. 23: 268-282

Jones, W. E., Demetropoulos, A. (1968). Exposure to wave action: Measurements of an important ecological parameter on rocky shores on Anglesey. J. exp. mar. Biol. Ecol. 2: $46-63$ 
Lewis, A. W. (1981). Edge waves and the dynamics of the nearshore environment. Ph. D. thesis, University of Wales

Mahéo, R. (1970). Étude de la pose et de l'activité de sécrétion du byssus de Mytilus edulis L. Cah. Biol. Inar. 11 : 475-483

Manley, A. R., Gruffydd, Ll. D., Almada-Villela, P. C. (1984). The effect of copper and zinc on the shell growth of Mytilus edulis measured by a laser diffraction technique. J. mar. biol. Ass. U.K. 64: 417-428

Martella, T. (1974). Some factors influencing byssus thread production in Mytilus edulis (Molluscs: Bivalvia) Linnaeus 1758. Wat. Air Soil Pollut. 3: 171-177

Moon, T. W., Pritchard, A. W. (1970). Metabolic adaptations in vertically separated populations of Mytilus californianus. J. exp. mar. Biol. Ecol. 5: 35-46

Paine, R. T., Levin, S. A. (1981). Intertidal landscapes: disturbance and the dynamics of pattern. Ecol. Monogr. 51: $145-178$

Pilgrim, R. L. C. (1953a). Osmotic relations in molluscan contractile tissues. I. Isolated ventricale strip preparations from lamellibranchs (Mytilus edulis L., Ostrea edulis L., Anodonta cygnea L.). J. exp. Biol. 30: 297-317

Pilgrim, R. L. C. (1953b). Osmotic relations in molluscan contractile tissues. II. Isolated gill preparations from lamellibranchs (Mytilus edulis L., Anodonta cygnea L.). J. exp. Biol. 30: 318-330

Price, H. A. (1980). Studies on the production and function of the byssus complex of Mytilus edulis L. Ph. D. thesis. University of Wales

Price, H. A. (1982). An analysis of factors determining seasonal variation in the byssal attachment strength of Mytilus edulis. J. mar. biol. Ass. U.K. 62: 147-155
Remane, A., Schlieper, C. (1971). Biology of brackishwater. Wiley-Interscience, New York

Scheer, B. (1945). The development of marine fouling communities. Biol. Bull. mar. biol. Lab., Woods Hole 89: 103-121

Schlieper, Von C. (1955). Über die physiologischen Wirkungen des Brackwassers. Kieler Meeresforsch. 11: 22-33

Segerstråle, S. G. (1957). Baltic Sea. In: Hedgpeth, J. W. (ed.) Treatise on marine ecology and paleoecology, Vol. 1, Ecology. National Research Council, New York, p. 751-800

Tamarin, A., Lewis, P., Askey, J. (1976). The structure and formation of the byssus attachment plaque in Mytilus. J. morph. 149: 199-222

Van Winkle, W. Jr. (1970). Effect of environmental factors on byssal thread formation. Mar. Biol. 7: 143-148

Vogel, S. (1981). Life in moving fluids. Willard Grant Press, Boston

Widdows, J., Bayne, B. L. (1971). Temperature acclimation of Mytilus edulis with reference to its energy budget. J. mar. biol. Ass. U.K. $51: 827-843$

Witman, J. D., Suchanek, T. H. (1984). Mussels in flow; drag and dislodgement by epizoans. Mar. Ecol. Prog. Ser. 16: 259-268

Young, G. A. (1983a). Bioadhesion of Mytilus edulis. Ph. D. thesis, University of Wales

Young, G. A. (1983b). Response to, and selection between, firm substrata by Mytilus edulis. J. mar. biol. Ass. U.K. 63: $653-659$ 